\title{
HUBUNGAN POLA ASUH ORANG TUA TERHADAP KEDISIPLINAN REMAJA DI SMPK SANTO VINCENTIUS SURABAYA
}

\author{
Aristina Halawa*, Jonathan Christopher** \\ Akper William Booth, halawaaristina@yahoo.co.id
}

\begin{abstract}
ABSTRAK
Pendahuluan: Pola asuh dalam keluarga merupakan sebuah hal yang penting yang harus dilakukan oleh orang tua dalam mengajarkan kedisiplinan pada anak, terutama pada masa remaja yang merupakan masa rentan bagi anak untuk terpengaruh hal-hal buruk yang ada di lingkungan sekitarnya. Tujuan dari penelitian ini adalah mengidentifikasi hubungan antara pola asuh orang tua terhadap kedisiplinan remaja di SMPK Santo Vincentius Surabaya. Metode: Penelitian ini menggunakan desain penelitian korelasional. Jumlah populasi pada penelitian ini adalah sebanyak 130 orang siswa kelas 8 dengan jumlah sampel yang digunakan sebagai responden penelitian adalah sebanyak 98 siswa. Pengambilan sampel dilakukan dengan cara Simple Random Sampling. Instrumen penelitian yang digunakan adalah kuesioner mengenai pola asuh orang tua dan kedisiplinan remaja. Hasil: Dari 98 responden didapatkan sebanyak 72 responden $(73,47 \%)$ mendapatkan pola asuh demokratis dan sebanyak 52 responden $(53,06 \%)$ memiliki kedisiplinan cukup. Hasil uji statistik dengan Korelasi Spearman menunjukkan nilai signifikasi (p) sebesar $0,036(\mathrm{p}<0,05)$ yang berarti terdapat hubungan antara pola asuh orang tua dengan kedisiplinan remaja. Diskusi: Pendekatan yang dilakukan oleh orang tua lewat pola asuh yang tepat merupakan kunci dalam mengajarkan disiplin kepada remaja. Oleh karena itu, diharapkan agar orang tua dapat menyediakan waktu untuk berdiskusi bersama dalam mengajarkankan kedisiplinan kepada remaja serta perhatian dalam melihat perubahan yang terjadi pada remaja sebagai proses dalam pembentukan kedisiplinan.
\end{abstract}

Kata kunci: Pola asuh orang tua, Kedisiplinan, Remaja.

\section{ABSTRACT}

Introduction: Parenting in family is an important thing that must been done by the parents to teach their children, especially on teenager's phase which is susceptible phase for children to influenced by bad things in the environment around them. The aims of this study is to identify the relation between parent's parenting with adolescent's discipline in Saint Vincentius J unior High School Surabaya. Methods: This study used correlation's study design. The amount of Population in this study are 130 students in eighth grades with total respondents are amount 98 students as the sample. Sampling decision was using simple random sampling method. The Instruments that used in this study were questionnaire about parent's parenting type and adolescent's discipline. Results: For about 72 of 98 respondents $(73,47 \%)$ were got authoritative parenting, and for amount 52 respondents $(53,06 \%)$ had fair category of discipline. Statistic test result with Spearman Correlation test was indicating signification level $(p)$ with value $0,036(p<0,05)$ that indicate that there is a relation between parent's parenting and adolescent's discipline. Discussions: The right way that used by the parents in parenting is the solution to teach discipline to the adolescent. Therefore to the parents, give a readiness to discuss together with the adolescent about discipline, and also always pay an attention with every change inside the adolescent as the process of shaping their discipline.

Key words: Parent's Parenting, Discipline, Adolescent. 


\section{PENDAHULUAN}

Dewasa ini, pola asuh dalam keluarga menjadi sebuah hal yang penting dalam mendidik anak. Pola asuh merupakan suatu cara yang dilakukan oleh orang tua dalam mendidik anak untuk menjadi pribadi yang lebih baik dan diharapkan dapat memiliki karakter-karakter yang paripurna, salah satunya adalah karakter disiplin. Namun masalah yang ditemui pada banyak kasus kedisiplinan remaja saat ini sangat bertolak belakang dari apa yang diharapkan. Banyak orang tua yang mengeluhkan anaknya dapat tumbuh menjadi anak yang tidak disiplin dan tidak sesuai dengan harapan orang tua, yang tampak dari perilaku keseharian yang menurut orang tua sangat menjengkelkan, sehingga dalam salah satu buku mengenai parenting dibuat rangkuman yang memuat 79 kasus mengenai remaja yang dikeluhkan oleh orang tua yang sebagian besar merupakan masalahmasalah yang terjadi akibat kurangnya disiplin diri pada remaja. Masa remaja merupakan masa transisi perkembangan antara masa anak dan masa dewasa, yang mulai mengalami perubahan pesat dalam berbagai aspek perkembangan dan mulai mencari jati diri dan tujuan hidupnya dalam menentukan masa depan yang akan diraih, salah satunya dengan mengamalkan nilai dan karakter yang telah didapatkan lewat pembelajaran dan pengajaran oleh orang tua dalam lingkungan keluarga, yaitu pembelajaran mengenai kedisiplinan. Seorang remaja dikatakan memiliki kedisiplinan apabila ia mampu mengendalikan dirinya dalam suatu keteraturan dan taat dalam menjalani aturan yang berlaku (Farida, 2014). Seharusnya remaja mulai berpikir dan menerapkan kedisiplinan lewat pengajaran yang baik dan perhatian penuh dari orang tua, sehingga remaja dapat meletakkan kedisiplinan tersebut menjadi suatu kebiasaan yang akan dibawa hingga dewasa kelak.

Pengamatan yang dilakukan peneliti mengenai masalah kedisiplinan telah dilakukan terhadap beberapa orang teman dari kerabat peneliti yang seluruhnya merupakan siswa kelas 9 SMP yang bersekolah di salah satu sekolah menengah pertama di Surabaya. Peneliti mendapatkan informasi bahwa sebagian besar dari mereka mengalami masalah ketidakdisiplinan seperti bangun kesiangan, lupa mengerjakan tugas sekolah, dan menggunakan sebagian waktu di rumah untuk bercanda gurau dengan teman lewat jejaring sosial lewat smartphone. Siswa yang mengalami masalah ketidakdisiplinan ini mengungkapkan bahwa mereka jarang diperhatikan dan jarang berkomunikasi dengan orang tua. Sedangkan remaja lain yang mengatakan bahwa mereka selalu hidup teratur mengungkapkan bahwa di rumah orang tua mereka telah membiasakan membuat jadwal-jadwal mengenai jam-jam kegiatan yang harus dilakukan sejak kecil dan sering menanyakan bagaimana kegiatan mereka di sekolah. Rendahnya disiplin remaja ini juga diperkuat oleh hasil penelitian yang dilakukan oleh Dani Ramdani (2010) pada murid SMP YMJ Ciputa, dimana dari 68 orang siswa, hanya sebanyak 44,5\% (30 orang) siswa yang memiliki kebiasaan untuk meminta ijin pada guru saat masuk dan keluar kelas, sebanyak $37,5 \%$ (25 orang) siswa yang memanfaatkan waktu luang di rumah untuk belajar, dan hanya sebanyak 24\% (16 orang) siswa yang memiliki kebiasaan menyiapkan alat dan bahan pelajaran. Syamsul Arifin dan Imam Hambali pada tahun 1994 (dalam Shochib, 2010) juga membuktikan bahwa kenakalan remaja disebabkan oleh kondisi keluarga yang negatif, seperti ketegangan keluarga, tingkat otoritas orang tua, dan miskinnya teladan keagamaan. Hubungan pola asuh terhadap kedisiplinan juga dibuktikan pada jurnal penelitian oleh Sera Sonita (2013,) bahwa pola asuh yang paling banyak digunakan oleh orangtua siswa SMP 12 Padang adalah pola asuh Authoritative atau demokrasi (32,03\%) dengan 90,63\% (116 orang) siswa memiliki disiplin baik.

Masalah disiplin muncul dari dua pikiran keliru yang diajarkan sejak kecil, dimana 1) bila kita tidak menyukai sesuatu atau sesuatu berjalan tidak adil, maka kita tidak harus melakukannya, dan 2) lebih mudah dan lebih baik menikmati kesenangan dengan segera ketimbang menyangkal diri dan mendapat kesenangan kelak (Hauck, 1991). Kurangnya perhatian orang tua terhadap anak menyebabkan kurangnya pemahaman orang tua mengenai kepribadian remaja secara utuh dan berdampak pada tidak sesuainya pola pengajaran yang dilakukan oleh orang tua terhadap remaja dalam memupuk karakter disiplin. Remaja secara naluriah memiliki rasa ingin tahu yang tinggi. Rasa ingin tahu yang timbul ini apabila tidak dilandasi konsep yang baik yang ditanamkan oleh orang tuanya lewat 
pengajaran atau pola asuh yang baik dan sesuai, maka akan mengarahkan remaja masuk dalam pengaruh yang buruk dari lingkungan lain seperti lingkungan pertemanan di sekolah dan di masyarakat. Konsep dan pemahaman yang bersifat negatif yang diterima remaja ini kemudian muncul dalam suatu perbuatan seperti melanggar aturan, membantah, tidak mau mendengarkan nasihat dan tidak menghargai waktu yang semuanya itu merupakan wujud ketidakdisiplinan diri pada remaja, yang kemudian dapat berdampak pada tertanamnya konsep yang salah dan menjadikan remaja berperilaku tidak disiplin. Ketidakdisiplinan yang berlangsung secara terus menerus akan berdampak pada kebiasaan berperilaku tidak disiplin. Pemahaman yang salah dimana remaja akan menganggap bahwa perilaku tersebut wajar dan memang seharusnya dilakukan oleh remaja yang sedang beranjak dewasa, akan membuat remaja menjadi individu yang malas untuk mengembangkan diri dan susah termotivasi untuk berubah menjadi lebih baik. Dan ketika ini sudah terjadi, remaja yang beranjak dewasa pun juga akan sulit diterima di masyarakat dan sulit bersaing terlebih di lingkungan kerja, karena lingkungan kerja pada saat ini lebih mengedepankan kompetisi terhadap kualitas individu yang salah satunya ditinjau dari kedisiplinan individu itu sendiri.

Dalam mewujudkan perilaku disiplin yang baik pada remaja, peran orang tua dalam memberikan pola asuh yang baik dan sesuai dengan karakter remaja menjadi sangat penting untuk dilakukan. Pemahaman mengenai cara mendidik dan menanamkan konsep yang baik mengenai kedisiplinan pada remaja serta didukung oleh pemahaman akan karakter remaja lewat pemberian perhatian dan komunikasi intens yang terjadi di dalam keluarga menjadi hal penting yang harus dipahami orang tua dalam mengajarkan kedisiplinan pada remaja. Ketegasan terhadap aturan-aturan dimana baik orang tua maupun remaja sama-sama menjalanannya dan ketersediaan untuk dikoreksi apabila terdapat pelanggaran terhadap aturan, dapat membantu remaja dalam mempersepsikan aturan yang berlaku, yang membuat remaja memiliki konsep disiplin yang benar dan mampu dibawa dan menjadi suatu kebiasaan yang baik dalam kehidupannya. Oleh karena itu, peneliti tertarik untuk melakukan penelitian mengenai hubungan pola asuh orang tua terhadap kedisiplinan remaja.

\section{METODE}

Berdasarkan tujuan penelitian desain penelitian yang digunakan adalah desain korelasional secara cross sectional yaitu merupakan rancangan penelitian dengan melakukan pengukuran atau pengamatan pada saat bersamaan (sekali waktu) (Nursalam, 2003).

Penelitian ini bertujuan untuk mengetahui hubungan pola asuh orang tua terhadap kedisiplinan remaja di SMPK Santo Vincentius Surabaya

Pada penelitian ini populasinya adalah seluruh siswa kelas VIII SMPK SantoVincentius

Surabaya, yang berjumlah 130 siswa

Kriteria populasi pada penelitian ini yaitu siswa yang bersekolah di SMPK Santo Vincentius Surabaya.

Setelah disesuaikan dengan kriteria penelitian, didapatkan sampel berjumlah 98 siswa. Dalam penelitian ini peneliti menggunakan teknik Simple Random Sampling, yaitu penetapan sampel dengan memilih secara acak namun tetap memperhatikan kuota masing-masing kelas.

Pengambilan data tentang pola asuh orang tua siswa kelas 8 SMPK Santo Vincentius Surabaya dan tingkat kedisiplinan siswa kelas 8 SMPK Santo Vincentius Surabaya dilakukan dengan menyebarkan kuisioner kepada responden. Dalam penelitian ini terdapat dua kategori kuesioner yakni kategori pola asuh orang tua dan kategori kedisiplinan remaja. Pada kategori pola asuh orang tua, terdapat 24 pernyataan yang tiap 8 pernyataan mewakili pola asuh orang tua, baik otoriter, demokratis, dan permisif. Pernyataan pada kuesioner bersifat tertutup dengan jawaban ya dan tidak, apabila pernyataan bersifat positif, pilihan "ya" merupakan pilihan yang sesuai dengan poin 1 (satu) dan pilihan "tidak" merupakan pilihan yang tidak sesuai dengan poin 0 (nol), dan apabila pernyataannya bersifat negatif, maka pilihan "tidak" merupakan pilihan yang sesuai dengan poin 1 (satu) dan pilihan "ya" merupakan pilihan yang tidak sesuai dengan poin 0 (nol), dengan kesimpulan penilaian tipe pola asuh orang tua didasari oleh pilihan sesuai terbanyak pada tiap tipe pola asuh orang tua, yang kemudian ditentukan sebagai pola asuh dominan yang digunakan orang tua remaja. Kategori kedisiplinan remaja, terdapat 33 
pernyataan yang masing-masing memiliki skor pernyataan. Apabila pernyataan bersifat positif, maka pilihan jawaban "selalu" mendapat skor 4, "sering" mendapat skor 3, "kadang-kadang" mendapat skor 2, dan "tidak pernah" mendapat skor 1 , dan sebaliknya apabila pernyataan bersifat negatif maka pilihan jawaban "selalu" mendapat skor 1, "sering" mendapat skor 2, "kadang-kadang" mendapat skor 3, dan "tidak pernah" mendapat skor 4. Kesimpulan akhir kedisiplinan remaja: Sangat Rendah (33-52), rendah (53-72), sedang (73-92), tinggi (93112), dan sangat tinggi (113-132) yang didasari oleh rentang dari nilai terendah; 33 (33 x 1), hingga nilai tertinggi; 132 (33 x 4), yaitu 100 poin, lalu rentang tersebut dibagi 5 , menjadi 20 poin per tiap kategori kedisiplinan remaja, sehingga didapatkan rentang-rentang kategori kedisiplinan remaja seperti yang telah ditetapkan diatas. Uji statistik yang digunakan dalam penelitian ini adalah korelasi Spearman. Uji Statistik Spearman.

\section{HASIL DAN PEMBAHASAN}

Karakteristik Responden berdasarkan jenis kelamin

Tabel 1. Karakteristik responden berdasarkan Jenis kelamin di SMPK Santo Vincentius Surabaya

\begin{tabular}{rccc}
\hline $\begin{array}{c}\text { N } \\
\text { o. }\end{array}$ & $\begin{array}{c}\text { Jenis } \\
\text { Kelamin }\end{array}$ & $\begin{array}{c}\text { Jumla } \\
\text { h } \\
\text { (f) }\end{array}$ & $\begin{array}{c}\text { Persenta } \\
\text { se }(\%)\end{array}$ \\
\hline 1 & Laki-laki & 48 & 48,98 \\
2 & Perempuan & 50 & 51,02 \\
\hline & Total & $\mathbf{9 8}$ & $\mathbf{1 0 0 , 0 0}$ \\
\hline
\end{tabular}

Berdasarkan tabel 1 dapat diketahui bahwa responden Perempuan merupakan responden terbanyak dengan jumlah 50 siswa $(51,02 \%)$.

Karakteristik responden berdasarkan usia

Tabel 2. Karakteristik responden berdasarkan usia di \begin{tabular}{cccc}
\multicolumn{4}{c}{ SMPK Santo Vincentius Surabaya } \\
\hline $\begin{array}{c}\mathrm{N} \\
\text { o. }\end{array}$ & Usia & $\begin{array}{c}\text { Ju } \\
\text { mlah } \\
\text { (f) }\end{array}$ & $\begin{array}{c}\text { Persentase } \\
(\%)\end{array}$ \\
\hline 1 & $\unlhd 12$ & 0 & 0 \\
2 & 13 & 36 & 36,73 \\
3 & 14 & 48 & 48,98 \\
4 & 15 & 12 & 12,24 \\
5 & $\geq 16$ & 2 & 2,04 \\
\hline
\end{tabular}

\begin{tabular}{rrr}
\hline Total & 98 & $\mathbf{1 0 0 , 0 0}$
\end{tabular}

Berdasarkan tabel 2 dapat diketahui bahwa responden yang berusia 14 tahun merupakan responden terbanyak dengan jumlah 48 siswa $(48,98 \%)$.

Karakteristik responden berdasarkan Urutan anak dalam keluarga

Tabel 3. Karakteristik responden berdasarkan Urutan anak dalam keluarga di SMPK Santo Vincentius Surabaya

\begin{tabular}{cccc}
\hline $\begin{array}{c}\mathrm{N} \\
\text { o. }\end{array}$ & $\begin{array}{c}\text { Urutan anak } \\
\text { dalam Keluarga } \\
\text { (Anak ke-) }\end{array}$ & $\begin{array}{c}\text { Jumlah } \\
\text { (f) }\end{array}$ & $\begin{array}{c}\text { Perse } \\
\text { ntase } \\
(\%)\end{array}$ \\
\hline 1 & 1 & 46 & $\begin{array}{l}46,9 \\
4\end{array}$ \\
2 & 2 & 34 & 34,6 \\
& & 11 & 11,2 \\
3 & 3 & 7 & 2 \\
4 & $\underline{4}$ & $\mathbf{4}, 14$ \\
\hline & Total & $\mathbf{9 8}$ & $\mathbf{1 0 0}$ \\
\hline
\end{tabular}

Berdasarkan tabel 3 dapat diketahui bahwa responden yang merupakan anak pertama dalam keluarga merupakan responden terbanyak dengan jumlah 46 siswa $(46,94 \%)$.

Karakteristik responden berdasarkan sarana ke sekolah

Tabel 4. Karakteristik responden berdasarkan sarana ke sekolah di SMPK Santo Vincentius Surabaya

\begin{tabular}{cccc}
\hline $\begin{array}{c}\text { N } \\
\text { o. }\end{array}$ & $\begin{array}{c}\text { Sarana ke } \\
\text { Sekolah }\end{array}$ & $\begin{array}{c}\text { Juml } \\
\text { ah } \\
\text { (f) }\end{array}$ & $\begin{array}{c}\text { Persenta } \\
\text { se (\%) }\end{array}$ \\
\hline 1 & Jalan Kaki & 6 & 6.12 \\
2 & Angkutan Umum & 5 & 5.10 \\
3 & $\begin{array}{c}\text { Sepeda } \\
4\end{array}$ & 21 & 21.43 \\
& $\begin{array}{c}\text { Kendaraan } \\
\text { Bermotor }\end{array}$ & 6 & 6.12 \\
Diantar Orang & 60 & 61.22 \\
\hline & Tua & $\mathbf{9 8}$ & $\mathbf{1 0 0 , 0 0}$ \\
\hline
\end{tabular}

Berdasarkan tabel 4 dapat diketahui bahwa responden yang diatar oleh orang tua merupakan responden terbanyak dengan jumlah 60 siswa (61.22\%). 


\section{Data Khusus}

Data khusus dalam bab ini menghubungan mengenai pola asuh orang tua dan kedisiplinan siswa SMPK Santo Vincentius Surabaya. Karakteristik dalam data khusus ini diantaranya adalah mengenai pola asuh orang tua siswa dan tingkat kedisiplinan siswa SMPK Santo Vincentius Surabaya.

Karakteristik Pola Asuh Orang Tua

Tabel 5. Karakteristik pola asuh orang tua responden di SMPK Santo Vincentius Surabaya

\begin{tabular}{cccc}
\hline $\begin{array}{r}\text { N } \\
\text { o. }\end{array}$ & $\begin{array}{c}\text { Pola Asuh Orang } \\
\text { Tua }\end{array}$ & $\begin{array}{c}\text { Juml } \\
\text { ah } \\
\text { (f) }\end{array}$ & $\begin{array}{c}\text { Persen } \\
\text { tase }(\%)\end{array}$ \\
\hline 1 & Demokratis & 72 & 73,47 \\
2 & Otoriter & 18 & 18,37 \\
3 & Permisif & 8 & 8,16 \\
\hline & Total & $\mathbf{9 8}$ & $\mathbf{1 0 0 , 0 0}$ \\
\hline
\end{tabular}

Berdasarkan tabel 5 dapat diketahui bahwa karakteristik responden dengan pola asuh orang tua yang demokratis merupakan responden terbanyak dengan jumlah 72 siswa $(73,47 \%)$.

Karakteristik Kedisiplinan Remaja

Tabel 6. Karakteristik kedisiplinan remaja responden di SMPK Santo Vincentius Surabaya

\begin{tabular}{cccc}
\hline $\begin{array}{c}\text { N } \\
\text { o. }\end{array}$ & $\begin{array}{c}\text { Kedisiplinan } \\
\text { Remaja }\end{array}$ & $\begin{array}{c}\text { Juml } \\
\text { ah } \\
\text { (f) }\end{array}$ & $\begin{array}{c}\text { Per } \\
\text { sentas } \\
\text { e (\%) }\end{array}$ \\
\hline 1 & Sangat Tinggi & 2 & 2,0 \\
2 & Tinggi & 38 & 38, \\
& & & 78 \\
3 & Cukup & 52 & 53, \\
4 & Rendah & 6 & 6,1 \\
& & & 06,0 \\
5 & Sangat Rendah & 0 & 0 \\
\hline & Total & $\mathbf{9 8}$ & $\mathbf{1 0 0}$ \\
\hline
\end{tabular}

Berdasarkan tabel 6 dapat diketahui bahwa karaktersitik responden dengan kedisiplinan cukup merupakan responden terbanyak dengan jumlah 52 siswa $(53,06 \%)$.
Tabulasi silang pola asuh orang tua dengan kedisiplinan remaja

Tabel 7. Distribusi frekuensi responden pola asuh remaja orang tua dengan kedisiplinan di SMPK Santo Vincentius Surabaya

\begin{tabular}{|c|c|c|c|c|}
\hline \multirow{2}{*}{$\begin{array}{l}\text { Kedisip } \\
\text { linan }\end{array}$} & \multicolumn{4}{|c|}{ Pola Asuh } \\
\hline & $\begin{array}{l}\text { Demo } \\
\text { kratis }\end{array}$ & $\begin{array}{l}\text { Oto } \\
\text { riter }\end{array}$ & $\begin{array}{l}\text { Per } \\
\text { misif }\end{array}$ & $\begin{array}{r}\mathbf{T} \\
\text { otal }\end{array}$ \\
\hline $\begin{array}{l}\text { Sangat } \\
\text { Tinggi }\end{array}$ & $\begin{array}{c}2 \\
(100 \\
\%)\end{array}$ & 0 & 0 & $\begin{array}{r}2 \\
(1 \\
00 \%)\end{array}$ \\
\hline Tinggi & $\begin{array}{c}30 \\
(78,9 \\
5 \%)\end{array}$ & $\begin{array}{c}8 \\
(21, \\
05 \%)\end{array}$ & $\begin{array}{c}0 \\
(0,0 \\
0 \%)\end{array}$ & $\begin{array}{r}38 \\
(1 \\
0 \%)\end{array}$ \\
\hline Cukup & $\begin{array}{c}38 \\
(73,0 \\
8 \%)\end{array}$ & $\begin{array}{c}8 \\
(15, \\
38 \%)\end{array}$ & $\begin{array}{c}6 \\
(11 \\
54 \%)\end{array}$ & $\begin{array}{r}52 \\
(1 \\
00 \%)\end{array}$ \\
\hline Rendah & $\begin{array}{c}2 \\
(33,3 \\
3 \%)\end{array}$ & $\begin{array}{c}2 \\
(33, \\
33 \%)\end{array}$ & $\begin{array}{c}2 \\
(33 \\
33 \%)\end{array}$ & $\begin{array}{r}6 \\
(1 \\
00,00 \\
\%)\end{array}$ \\
\hline \multirow[t]{2}{*}{$\begin{array}{l}\text { Sangat } \\
\text { Rendah }\end{array}$} & $\begin{array}{c}0 \\
(0,00 \\
\%)\end{array}$ & $\begin{array}{c}0 \\
(0,0 \\
0 \%) \\
\end{array}$ & $\begin{array}{c}0 \\
(0,0 \\
0 \%) \\
\end{array}$ & $\begin{array}{r}0 \\
(0 \\
, 00 \%) \\
\end{array}$ \\
\hline & & & Total & $\begin{array}{r}98 \\
\text { Oran } \\
\mathbf{g} \\
\end{array}$ \\
\hline $\begin{array}{l}\text { Uji Stati } \\
\text { signifikansi } \\
\text { Correlation i }\end{array}$ & $\begin{array}{l}\text { Spearn } \\
\text { snificant }\end{array}$ & $\begin{array}{l}\text { 'Rho } \\
= \\
\text { the } 0,0\end{array}$ & $\begin{array}{l}\text { orrelatio } \\
\text { evel (2-ts }\end{array}$ & $\begin{array}{l}\text { hasil } \\
0,036 \\
\text { led) }\end{array}$ \\
\hline
\end{tabular}

Berdasarkan tabel 7 hasil tabulasi silang antara pola asuh orang tua dengan kedisiplinan remaja, didapatkan hasil persebaran data sebagai berikut. Kedisiplinan remaja kategori rendah tersebar rata antara ketiga pola asuh, yaitu masing-masing sebanyak 2 siswa $(33,33 \%)$. Pada kategori kedisiplinan remaja cukup, jumlah remaja yang mendapatkan pola asuh demokratis yaitu 38 siswa $(73,08 \%)$, pada remaja dengan pola asuh Otoriter sebanyak 8 siswa $(15,38 \%)$ dan pada remaja dengan pola asuh orang tua yang permisif terdapat 6 siswa $(11,54 \%)$. Pada karakteristik kedisiplinan remaja yang tinggi, terdapat sebanyak 30 siswa $(78,95 \%)$ remaja dengan pola asuh demokratis, 8 siswa $(21,05 \%)$ dengan pola asuh Otoriter dan tidak terdapat karakteristik remaja dengan kedisiplinan tinggi pada pola asuh Permisif. Remaja yang mendapatkan pola asuh demokratis oleh orang tuanya menjadi satusatunya pola asuh yang terdapat pada kategori 
kedisiplinan remaja sangat tinggi dengan jumlah 2 siswa $(100,00 \%)$. Hasil uji statistik Spearman's Rho Correlation dengan nilai signifikansi (p) 0,05 (2-tailed) didapatkan hasil 0,036. Dengan hasil p kurang dari 0,05, ini menandakan bahwa hipotesis $\mathrm{H} 1$ diterima, sehingga dapat disimpulkan bahwa terdapat hubungan antara pola asuh orang tua terhadap kedisiplinan remaja di SMPK Santo Vincentius Surabaya.

\section{PEMBAHASAN}

\section{Pola Asuh Orang Tua pada Siswa Kelas 8 di SMPK Santo Vincentius Surabaya}

Hasil mengenai jumlah pola asuh orang tua pada siswa kelas 8 di SMPK Santo Vincentius Surabaya ditunjukkan pada tabel 5 dimana pola asuh demokratis diterapkan pada 72 siswa $(73,47 \%)$, pola asuh otoriter terdapat pada 18 siswa $(18,37 \%)$ dan pola asuh permisif ada pada 8 siswa $(8,16 \%)$. Dari hasil tersebut, dapat disimpulkan bahwa pola asuh demokratis merupakan pola asuh yang paling banyak diterapkan pada remaja siswa kelas 8 di SMPK St Vincentius Surabaya. Menurut teori yang dikemukakan oleh Duvall dan Miller (dalam Friedman, 1998) mengenai tahapan tugas perkembangan keluarga, keluarga dengan anak remaja bertugas untuk memberikan kebebasan dan tanggung jawab kepada anak dengan tetap mempertahankan komunikasi yang terbuka antara anak dan orang tua. Tugas keluarga dengan anak usia remaja sendiri adalah memberikan pengajaran dengan cara saling sharing, memberikan anak kebebasan dalam berpendapat dan menentukan keputusan namun tetap mengarah pada aturan dan bimbingan yang sesuai yang telah disepakati bersama antara anak dan orang tua. Proses didikan dan pendekatan ini merupakan cara yang dilakukan pada orang tua kepada remaja sesuai dengan tahap perkembangan keluarga dengan anak remaja ini menjadi jawaban mengapa pola asuh demokratis merupakan pola asuh dominan yang diterapkan oleh orang tua kepada anak remaja mereka di SMPK Santo Vincentius Surabaya.

Pola asuh demokratis yang merupakan pola asuh terbanyak yang ditemukan pada siswa kelas 8 di SMPK Santo Vincentius Surabaya juga berkaitan dengan jumlah anak dalam keluarga, seperti yang terdapat pada tabel 3 mengenai urutan anak dalam keluarga. Dalam tabel tersebut dapat dilihat bahwa jumlah siswa yang memiliki kedudukan sebagai anak pertama merupakan siswa terbanyak dengan jumlah 46 siswa (46,92\%). Hal ini sejalan dengan teori yanag dikemukakan oleh Hurlock (1980) bahwa jumlah anak dalam keluarga mempengaruhi pola asuh yang diterapkan oleh orang tua kepada anaknya. Orang tua dengan jumlah anak kurang dari dua sangat mungkin memberikan perhatian yang lebih kepada anaknya baik dalam setiap kesehariannya di sekolah maupun di dalam rumah. Orang tua akan menanyakan apa saja aktivitas yang dilakukan anak di sekolah, apakah pelajarannya menyenangkan, bagaimana pergaulannya di sekolah, dan lain-lain yang menunjukkan perhatian orang tua kepada anak di lingkungan sekolahnya. Orang tua berharap agar pemahaman dan juga didikan yang mereka berikan kepada anaknya dapat tertanam dengan baik dalam diri sehingga nantinya anak dapat menerapkan pemahaman tersebut secara baik apabila di kemudian hari orang tua memiliki anak lagi dan si anak tersebut dapat bersosialisasi dan memberikan pengaruh positif kepada anaknya.

Pada tabel 4 yang menunjukkan data mengenai sarana siswa ke sekolah, ditemukan bahwa siswa yang berangkat sekolah diantar oleh orang tuanya merupakan jumlah terbanyak dibandingkan sarana lainnya, dengan jumlah 60 siswa $(61,22 \%)$, lebih dari setengah dari sampel penelitian. Hal ini sesuai dengan teori yang dikemukakan oleh Diana Baumrind bahwa perhatian dan juga bimbingan yang diberikan oleh orang tua kepada anak berlangsung secara baik apabila orang tua juga turut berperan aktif secara nyata dalam memberikan perhatian dan bimbingan pada anak. Orang tua tidak ingin anaknya mendapat kendala saat berangkat sekolah dan memastikan bahwa anak sampai di sekolah dalam keadaan selamat. Disamping itu, dengan mengantar anak ke sekolah, orang tua secara aktif menumbuhkan rasa ingin tahunya terhadap lingkungan sekolah yang menjadi rumah kedua anak dalam menjalani proses belajar, bersosialisasi dan perkembangan kedisiplinan anak.

\section{Kedisiplinan Remaja pada Siswa Kelas 8 di SMPK St Vincentius Surabaya}

Kedisiplinan remaja yang terdapat pada siswa kelas 8 di SMPK Santo Vincentius Surabaya yang ditemukan dari hasil pengumpulan data kuisioner ternyata 
mayoritas berada pada kategori kedisiplinan cukup. Pernyataan ini dibuktikan pada tabel 6 mengenai karakteristik kedisiplinan remaja responden di SMPK Santo Vincentius Surabaya, dimana jumlah responden dengan kategori kedisiplinan cukup ditemukan pada 52 siswa $(53,06 \%)$, lebih dari separuh jumlah responden secara keseluruhan. Soegeng Prijodarminto (dalam Sonita, 2013) menyatakan bahwa kedisiplinan pada remaja terjadi akibat suatu proses yang kompleks, dimana melibatkan peran serta orang tua secara kodrat dan juga lingkungan eksternal lain, dalam hal ini sekolah. Teori tersebut juga diperkuat oleh teori yang dikemukakan oleh Maman Surahman (dalam Sonita, 2013) yang menyatakan bahwa kedisiplinan dapat dipengaruhi oleh banyak faktor, baik yan berasal dari dalam diri remaja, maupun lingkungan di sekitar remaja. Masa remaja awal masuk dalam kategori anak usia sekolah, dimana sebagian besar waktunya dihabiskan dalam lingkungan sekolah. Hampir setengah hari usia remaja awal dihabiskan didalam sekolah seperti belajar, menyelesaikan tugastugas, dan bersosialisasi dengan teman-teman sebaya dan para guru di sekolah. SMPK Santo Vincentius menerapkan kegiatan "Perwalian" yang dijadwalkan setiap hari senin pada jam pertama merupakan kegiatan pendekatan yang dilakukan antara guru wali kelas dengan para siswa, dimana kegiatan ini berfokus untuk memberikan perhatian kepada siswa baik dalam hal kedisiplinan dan kegiatan belajarmengajar. Penulis mengamati kegiatan perwalian di beberapa kelas, dimana salah satu guru wali kelas memberikan nasihat mengenai pentingnya membiasakan disiplin sejak usia remaja karena ada satu anak murid yang datang terlambat ke sekolah disaat bel tanda masuk telah berbunyi. Begitupun di kelas lain, wali kelas tampak membantu beberapa murid yang tampak kesulitan dalam mempersiapkan prakarya yaitu sarana belajar dalam mata pelajaran matematika. Dengan melihat hasil pengamatan pada proses bimbingan dan arahan yang diberikan oleh wali kelas kepada para murid lewat kegiatan "Perwalian" diatas, kita dapat mengetahui bahwa proses bimbingan ini berjalan secara intens. Namun hal ini tidak dibarengi dengan penghayatan para murid terhadap makna atau esensi dibalik kegiatan bimbingan yang dilakukan oleh guru wali kelas, yaitu mencoba menanamkan konsep kedisiplinan secara pelan dan bertahap. Murid menganggap bahwa bimbingan yang diberikan ini hanya sekadar rutinitas penambahan materi pelajaran saja, yang wajib diikuti oleh setiap siswa tanpa penghayatan lebih dalam mengenai tujuan pembinaan disiplin dari kegiatan "Perwalian" ini, sehingga banyak murid tetap pada perilaku awalnya sebagai seorang remaja yang masih mencari tahu mengenai konsep moral kedisiplinan yang sesuai untuk dirinya yang terbukti dari nilai kategori kedisiplinan cukup yang dominan didapatkan pada data penelitian.

Apabila ditinjau dari tabel 2 mengenai usia responden, remaja dengan usia 14 tahun, yaitu sebanyak 48 siswa $(48,98 \%)$ merupakan kategori usia terbanyak yang ditemukan. Berdasarkan data tersebut, dapat dikatakan bahwa mayoritas siswa kelas 8 SMPK Santo Vincentius Surabaya merupakan anak usia remaja. Hal ini sesuai dengan konsep yang dikemukanan oleh Hurlock (1980) bahwa secara psikis, remaja awal (rentang usia 12 - 15 tahun) cenderung masih bersifat egosentris, yaitu mengandalkan emosionalitas diri dan kurang mampu menerima pendapat orang lain. Teori tersebut juga diperkuat oleh pendapat yang disampaikan oleh Tulus Tu'u (dalam Sonita, 2013) bahwa remaja memiliki penilaiannya sendiri dalam menilai seseorang dan mematuhi aturan yang diberikan oleh orangorang di sekitarnya. Remaja awal menilai sesuatu hal berdasarkan sudut pandangnya, dan merasa dirinya mampu menyelesaikan masalah yang dihadapi dengan caranya sendiri tanpa meminta saran terlebih dahulu kepada orang tua atau gurunya. Remaja menganggap bahwa dirinya telah memiliki konsep diri yang benar, yang didapatkan dari lingkungan diluar keluarga seperti lingkungan teman sepermainan dan media informasi yang diakses (contoh: televisi dan internet) yang belum tentu tepat bahkan bisa menjerumuskan remaja ke arah yang tidak baik. Hal ini menyebabkan ajaran mengenai kedisiplinan yang diberikan oleh orang tua dan guru akan dengan mudahnya diabaikan oleh remaja, sehingga remaja terjerumus untuk meniru apa yang mereka lihat dan dapatkan dari lingkungan diluar keluarga dan jatuh ke dalam penurunan kedisiplinan diri.

\section{Hubungan antara Pola Asuh Orang Tua terhadap Kedisiplinan Remaja}

Berdasarkan

pembahasan

mengenai pola asuh orang tua dan kedisiplinan 
remaja yang didapat dari responden di SMPK Santo Vincentius Surabaya pada subjek penelitian siswa kelas 8 menunjukkan hasil bahwa terdapat hubungan antara pola asuh orang tua yang demokratis terhadap kedisiplinan remaja. Hal ini dapat dilihat pada tabel 7 mengenai distribusi frekuensi kedisiplinan dari ketiga pola asuh, dimana kedisiplinan sangat tinggi hanya terdapat pada responden dengan pola asuh Demokratis, yaitu sebanyak 2 siswa (100\%), dan dilanjutkan dengan kedisiplinan tinggi yang paling banyak terdapat pada pola asuh demokratis, yaitu sebanyak 30 siswa $(78,95 \%)$. Hal ini juga dibuktikan oleh hasil uji statistik yang dilakukan dengan menggunakan analisa korelasi Spearman's Rho yang menunjukkan hasil signifikansi (p) sebesar 0,036 ( $<<0,05)$ sehingga hipotesis $\mathrm{H} 1$ diterima dan menyatakan bahwa terdapat hubungan antara pola asuh orang tua terhadap kedisiplinan remaja di SMPK Santo Vincentius Surabaya. Dalyono (dalam Irvan, 2014) mengemukakan lingkungan keluarga, yang merupakan salah satu faktor eksternal, sangat besar pengaruhnya terhadap pertumbuhan dan perkembangan anak yang salah satunya adalah kedisiplinan. Hal ini juga didukung oleh penelitian Istianah A. Rahman (2008) bahwa peran keluarga dapat memberikan dasar dalam pembentukan sikap, kualitas kepribadian, dan kedisiplinan remaja. Mulai sejak lahir sampai memasuki tahap remaja, lingkungan keluarga menjadi lingkungan yang paling sering ditemui anak. Anak belajar dan mengamati bagaimana lingkungannya bekerja dan memberikan pengaruh terhadap dirinya, baik dalam tumbuh dan kembangnya. Anak dapat mengambil sebuah kesimpulan dari cara orang tua berperilaku dan mendidik, dan menjadikannya sebagai sebuah konsep dasar yang kemudian tertanam dalam diri anak, salah satu bentuknya adalah perilaku disiplin. Hasil data penelitian hubungan pola asuh terhadap kedisiplinan remaja membuktikan bahwa kategori kedisiplinan sangat tinggi hanya terdapat pada pola asuh demokratis dan kategori kedisiplinan tinggi pada remaja dengan pola asuh demokratis memiliki angka yang paling tinggi dibandingkan pola asuh lain. Orang tua yang menerapkan bimbingan dengan pendekatan yang demokratis pada anak pada usia remaja, cenderung menjadikan remaja memiliki karakter kedisiplinan yang baik. Pendekatan yang dilakukan secara hangat lewat 'sharing discussion' diskusi dua arah dimana ada kesediaan orang tua untuk mendengar pedapat dari remaja dan komitmen dalam menaati aturan yang telah ditetapkan bersama-sama baik antara orang tua dan remaja, menimbulkan suatu penerimaan yang baik oleh remaja terhadap aturan tersebut. Dengan cara-cara pendekatan orang tua kepada remaja secara demokratis seperti ini, orang tua akan mampu membimbing dan mengarahkan remaja untuk memiliki pemahaman dan penerapan kedisiplinan yang tinggi.

Data mengenai hubungan pola asuh orang tua terhadap kedisiplinan remaja juga dapat dilihat dari sudut pandang yang berbeda, dimana data bahwa pola asuh terbanyak yang digunakan pada siswa adalah pola asuh demokratis dengan jumlah 72 anak $(73,47 \%)$ dan kategori kedisiplinan terbanyak ada pada kategori kedisiplinan cukup dengan jumlah 52 siswa $(53,06 \%)$. Hal ini diperkuat oleh teori remaja yang terdapat pada Piadmajha (2013) yang menjelaskan bahwa masa remaja awal merupakan masa dimana remaja masih mempertahankan sifat keegosentrisannya, dan juga didukung oleh teori keluarga yang dikemukakan oleh Duvall dan Miller (Friedman, dalam Materi Kuliahku, 2013) yang menyatakan bahwa pada masa keluarga dengan anak usia remaja, keluarga secara perlahan mulai melepas otoritasnya dan memberikan kelonggaran kepada remaja untuk bersosialisasi dengan lingkungan. Pada pola asuh demokratis, orang tua lebih menekankan pada diskusi bersama dengan remaja untuk mendengarkan pendapatnya mengenai cara mendidik. Hal inilah yang dimanfaatkan oleh remaja dengan konsep mengenai pemahaman disiplin yang keliru; yang ia dapatkan dari pengaruh lingkungan yang kurang baik, untuk terus meminta permakluman kepada orang tua dan membicarakan terus untuk diberikan kelonggaran terhadap perbuatan salah dan ketidak disiplinan yang ia buat, sehingga orang tua yang bersikap demokratis pun kemudian memberikan toleransi dan pengertian yang maknanya tidak lagi diserap dengan baik oleh remaja, sehingga membuat anak tetap mempertahankan karakter kedisiplinan yang keliru tersebut.

Pola asuh demokratis yang memiliki kategori kedisiplinan remaja sangat tinggi tidak menandakan bahwa pola asuh demokratis merupakan satu-satunya pola asuh yang baik untuk diterapkan oleh orang tua pada remaja. Begitu pun pada pembahasan 
yang menjelaskan kelemahan dari penggunaan pola asuh demokratis secara penuh kepada remaja dengan pemahaman kedisiplinan yang keliru yang membuat kedisiplinan justru tidak berkembang. Data hubungan pola asuh orang tua terhadap kedisiplinan pada tabel 7 yang memperlihatkan bahwa kategori kedisiplinan tinggi sama-sama terdapat pada dua tipe pola asuh, yaitu pola asuh demokratis sejumlah 30 siswa $(78,95 \%)$ dan pola asuh otoriter dengan jumlah 8 siswa $(21,05 \%)$. Sejalan dengan pendapat yang dikemukakan oleh Dr. Rose Mini (dalam artikel "Pola Asuh yang Paling Banyak Dianut Orangtua", Majalah Mother\&Baby, 2015) bahwa derajat kehangatan dan kontrol orangtua harus bisa berjalan dengan seimbang sesuai dengan kondisi yang ada. Sejalan dengan hal tersebut, Ayah Edy (Ayah Edy, 2015) juga menyatakan bahwa dalam mewujudkan kedisiplinan pada anak, penegasan dengan metode reward and punishment yang disertai dengan penyesuaian terhadap aturan apabila remaja telah menunjukkan perkembangan kedisiplinan yang baik. Situasi yang terjadi pada remaja awal dalam lingkungannya tidak selalu sama setiap harinya. Remaja awal yang mudah meniru apa yang mereka lihat pada lingkungan sekitarnya sebagai wujud keingintahuan terhadap jati dirinya (misal contoh: karakter dalam kartun, film, maupun orang-orang lain di sekitar remaja) tidak jarang membuat remaja awal berubah-ubah baik dalam sikap dan perilaku, termasuk dalam hal disiplin. Oleh sebab itu, ada kalanya orang tua harus fleksibel dalam merespon perubahanperubahan yang terjadi pada diri remaja awal, yaitu dengan menyesuaikan bahkan mengkombinasikan pola asuh yang mereka berikan kepada remaja. Contoh apabila dalam memutuskan aturan awal yang hendak disepakati bersama, orang tua dapat secara demokratis menanyakan dan mendengarkan pendapat dari remaja yang sekiranya relevan terhadap aturan tersebut untuk kemudian ditetapkan sebagai aturan. Namun apabila ternyata remaja melanggar aturan yang telah ditetapkan itu tanpa alasan, orang tua berhak untuk secara otoriter bertindak tegas kepada remaja dan mengingatkan kembali tentang kesepakatan yang telah diambil bersama sewaktu menetapkan aturan tersebut.

\section{SIMPULAN}

Kesimpulan yang didapat dari penelitian ini adalah sebagai berikut:

Pola asuh orang tua yang dipergunakan kepada siswa kelas 8 SMPK Santo Vincentius Surabaya secara umum adalah pola asuh Demokratis.

Kedisiplinan remaja yang terdapat pada siswa kelas 8 SMPK Santo Vicentius Surabaya secara umum berada pada kategori kedisiplinan cukup.

Terdapat hubungan antara pola asuh orang tua terhadap kedisiplinan remaja pada siswa kelas 8 SMPK Santo Vincentius Surabaya.

\section{SARAN}

Diharapkan untuk dapat menerapkan pola asuh demokratis pada anak usia remaja secara tepat, dan juga dibarengi dengan kontrol positif dalam memantau perkembangan kedisiplinan remaja.

Diharapkan pendekatan yang dilakukan oleh pihak sekolah melalui para wali kelas pada program kegiatan Perwalian ini dapat lebih memberi makna bagi para siswa, agar para siswa menyadari pentingnya Perwalian sebagai wadah pembentukan kedisiplinan.

\section{DAFTAR PUSTAKA}

Atkinson, L. Rita, Richard C. Atkinson, Edward E. Smith, Darly J. Bean. 2000. Pengantar Psikologi. Ed. 11 Jilid 1. Jakarta: Interaksara.

Ayah Edy. 2015. Menjawab Problematika Orang Tua ABG \& Remaja. Jakarta: Noura Books.

Farida, Anna. 2014. Pilar-pilar Pembangunan Karakter Remaja. Bandung: Nuansa Cendekia.

Ginting, Leo. 2008. "Proposal Penelitian Hubungan Pola Asuh Orangtua terhadap Pembentukan Konsep Diri: Harga Diri pada Remaja di Depok". Fakultas Ilmu Keperawatan Universitas Indonesia.

https://www.academia.edu/973579 1/Proposal_Penelitian_Hubungan_ Pola_Asuh_Orangtua_dengan_Pe mbentukan_Konsep_Diri_Harga_ Diri_Remaja_di_Depok_. Diakses pada Februari 2017. 
Hidayat, A. Aziz Alimul. (2003). Riset Keperawatan dan Teknik Penelitian Ilmiah. Jakarta: Salemba Medika

Huck, Paul. 1991. Psikologi Populer: Mendidik Anak dengan Berhasil. Jakarta: Arcan.

Hurlock, B. Elisabeth. 1980. Psikologi Perkembangan: Suatu Pendekatan Sepanjang Rentang Kehidupan. Jakarta: Erlangga.

Itayanti, Agung, Pandeirot M. Nancye. 2014. "Hubungan Pola Asuh Orang Tua dengan Harga Diri Remaja di Banjar Pengenderan KedongananKuta" dalam Jurnal Keperawatan Vol. 3. No. 2. November 2014. Hal. 52 - 60. Surabaya: STIKes William Booth Surabaya.

Novem Hari. 2012. "Pengaruh Kebudayaan Jawa Timur Terhadap Pola Asuh Orang Tua Terhadap Anak Dirumah Saya" https://novemhariw353. wordpress.com/2012/03/18/pengar uh-kebudayaan-jawa-timurterhadap-pola-asuh-anak-dirumah/ diakses pada April 2017.

Nurhayanti, Rida, Dwi Novotasari, Natalia. 2013. "Tipe Pola Asuh Orang Tua yang berhubungan dengan Perilaku Bullying di SMA Kabupaten Semarang" dalam Jurnal Keperawatan Jiwa Vol. 1. No.1. Mei 2013. Hal. 49 - 59. Semarang: STIKes Ngudi Waluyo Ungaran.

Nursalam. 2011. Konsep dan Penerapan Metodologi Penelitian Ilmu Keperawatan: Pedoman Skripsi, Tesis, dan Instrumen Penelitian Keperawatan. Jakarta: Salemba Medika.

Piadmajha, Ananda. 2013. "Perkembangan Masa Remaja" http://ananda priadmajha.blogspot.co.id/2013/05/ perkembangan-masa-remaja.html. diakses pada April 2017.

Rahman, A. Istianah. 2008. "Hubungan antara Persepsi Terhadap Pola Asuh Demokratis Ayah dan Ibu dengan Perilaku Disiplin Remaja" dalam Lentera Pendidikan Vol. 11. No.1. Juni 2008. Hal. $69-82$. Yogyakarta: UGM.

Ramdani, Dani. 2010. "Disiplin Belajar Siswa SMP YMJ Ciputat dan
Hubungannya dengan Prestasi Belajar". Jakarta: Jurusan Kependidikan Islam, Program Studi Manajemen Pendidikan, Fakultas Ilmu Tarbiyah dan Keguruan, Universitas Islam Negeri Syarif Hidayatullah.

Riduwan. 2009. Dasar-dasar Statistika. Bandung: Alfabeta.

Setiadi. 2007. Konsep \& Penulisan Riset Keperawatan. Yogyakarta: Graha Ilmu.

Sonita, Sera. 2013. "Hubungan antara Pola Asuh Orang Tua dengan Disiplin Siswa di Sekolah" dalam KONSELOR: Jurnal Ilmiah Konseling Vol. 2. No. 1 Januari 2013. Hal. 174 - 181. Padang: Jurusan Bimbingan dan Konseling, Fakultas Ilmu Pendidikan, Universitas Negeri Padang.

Rimm, Sylvia. 1997. Why Bright Kids Get Poor Grades. Jakarta: Gramedia Widiasarana Indonesia.

Santrock, W. John. 2007. Remaja Jilid 1 Ed.11. Jakarta: Erlangga.

Shochib, Moh. 2010. Pola Asuh Orang Tua : Dalam Membantu Mengembangkan Disiplin Diri sebagai Pribadi yang Berkarakter. Jakarta: Rineka Cipta.

Somaryanti, Sri Astutik. 2013. "Family Therapy dalam Menangani Pola Asuh Orang Tua yang Salah pada Anak Slow Learner" dalam Jurnal Bimbingan dan Konseling Islam Vol. 03. No. 1. Hal. 17 35. Surabaya: Jurusan Bimbingan dan Konseling Islam. Fakultas Dakwah IAIN Sunan Ampel Surabaya. http://jurnalbki.uinsby.ac.id/ index.php/jurnalbki/article/downl oad/4/2. Diakses pada Februari 2017.

Yusuf, L. N. Syamsu, Nani M. Sugandhi. 2014. Perkembangan Peserta Didik: Mata Kuliah Dasar Profesi (MKDP) Bagi Para Mahasiswa Calon Guru di Lembaga Pendidikan Tenaga Kependidikan (LPTK). Jakarta: Rajawali Pers. 